\title{
High-Tech Entrepreneurship in Europe: A Heuristic Firm Growth Model and Three "(Un-)easy Pieces" for Policy-Making
}

\author{
LUCA GRILLI \\ Department of Management, Economics and Industrial Engineering, Politecnico di Milano, Via R. Lambruschini 4/b, \\ 20156 Milan, Italy
}

\begin{abstract}
Increasing the number of rapid-growth new technology-based firms (NTBFs) is considered one of the key priorities of innovation policy adopted by the European Commission. Grounded in the empirical literature on the determinants of high-tech start-up growth in Europe, this paper develops a heuristic firm growth model for European NTBFs to individuate three primary areas of intervention for policy-making aimed to sustain the growth of NTBFs: (i) reducing the social and regulatory burdens arising from (honest) firm failure, (ii) acknowledging the local nature of the venture capital industry and promoting territorial marketing initiatives to attract (international) venture capitalist players and (iii) leveraging the "halo and certification" effect of directs public subsidies and grants towards NTBFs. If recent initiatives of the European Commission go in these directions, much remains to be done to increase the growth potential of high-tech start-ups on the European landscape.
\end{abstract}

\section{Introduction}

The Europe 2020 agenda has renewed the Lisbon strategy goal of developing a European economy based on knowledge and innovation. The latter dimensions are deemed key inputs in enabling diffused "smart and sustainable" economic growth, which represents the primary European Union (EU) policy target. Accordingly, one of the main indicators with which advancement towards this goal is measured is the ratio of research and development (R\&D) expenditure to gross domestic product, which, by 2020 , should reach an average of 3 per cent

Correspondence Address: Luca Grilli, Department of Management, Economics and Industrial Engineering, Politecnico di Milano, Via R. Lambruschini 4/b, 20156 Milan, Italy. Tel.: + 39022399 3955. Fax: + 390223992710.

Email: luca.grilli@polimi.it 
in the enlarged EU of 27 countries. Whether the 2020 target is realistic is debatable, as most of the countries are well below the settled target (Source: Eurostat 2013); however, both the need to intervene to increase EU expenditures on R\&D activities and the specific areas on which to focus major efforts in this respect are less arguable. In particular, one important cause of the inadequate innovation performance of the EU is individuated in the insignificant presence of high-tech rapid-growth entrepreneurial firms. According to the Europe 2020 agenda (European Commission 2010, 10), "R\&D spending in Europe is below $2 \%$, compared to $2.6 \%$ in the United States (US). [ ... ] Our smaller share of high-tech firms explains half of our gap with the US". Firms such as Microsoft, Google and Genentech were high-tech start-ups that were able to launch and dominate new industry segments. This type of firm abounds in the USA, but they are relatively rare on the old continent. The creation of rapid-growth new technology-based firms, henceforth NTBFs (also high-tech entrepreneurial ventures), ${ }^{1}$ represents one qualifying point of every policy agenda at the European level in the short- and long-term future. Accordingly, understanding how to generate rapid-growth NTBFs in Europe and the role of public policy in this domain are fundamental and compelling questions.

Given this picture, the aim of this paper is twofold, one of academic nature and the other one of policy-oriented quality. First, we condense and synthesise the sparse scientific evidence on the determinants of (European) NTBF growth to provide a simplified and solid interpretative framework for the phenomenon. In fact, if there is more than a study that reviews the drivers of firm growth, there are no systematic efforts restricted to NTBFs in the European context. We contribute to fill this gap. Despite of the fact that the validity of the heuristic model goes behind Europe, we will maintain, whenever possible, a European focus and corroborate our statements using the scientific empirical literature produced in this specific geographical context. In doing so, we aim at enriching our insights on entrepreneurial dynamics in high-tech sectors under an institutional perspective, by enlightening peculiarities (and commonalities) of the European context compared to others. Second, this specific focus brings robustness to our analysis in the eyes of European policymakers. Thus, once identified the key drivers of European NTBF growth, our second objective is to derive three important areas of intervention for European policy-making in the field of high-tech entrepreneurship.

The remainder of the paper is organised as follows. In Section 2, we illustrate the heuristic firm growth model for NTBFs in Europe. This model will be the basis in Section 3 for the individuation of the three "(un-)easy" areas of intervention for European high-tech entrepreneurship policy. Section 4 concludes the paper.

\section{Heuristic Firm Growth Model for NTBFs in Europe}

Firm growth is a multifaceted phenomenon often characterised by idiosyncratic drivers and complex to analyse as to its determinants (Penrose 1959). NTBF growth clearly does not

\footnotetext{
${ }^{1}$ NTBF is a term for a category of firms that was originally coined by Arthur D. Little (1977) and identifies independently owned businesses that are young, active in technology-intensive industries and based on innovative activities. Here, we identify high-tech entrepreneurial ventures with this acronym and consider them synonyms. We use the term NTBF because it is still widely adopted in the EU policy arena (since the special issue in Research Policy 1998 edited by Storey and Tether, see European Commission 2000 or several recent country report from OECD) and by the scientific community (e.g. Czarnitzki and Delanote, 2013).
} 
represent an exception to this rule. Accordingly, different scientific lenses and methodological perspectives have been adopted in studying the phenomenon. In what follows, we present a heuristic firm growth model for European NTBFs. The model is given in Figure 1. Based on a review of the empirical literature in the business and economics fields, this heuristic representation outlines the primary causal inputs responsible for NTBF growth and highlights the main interrelationships across different actors. In doing that, the focus will be concentrated on those causal relationships that appear most solid in the light of the European-based evidence. We will analyse the model in detail, and the discussion will revolve around three fundamental building blocks: knowledge capital, financial resources and complementary assets. For each block, we will specify who are the key actors involved and which are their main functions.

\subsection{Knowledge Capital}

Founders' human capital is a key asset for new firms in general (Chandler and Hanks 1994) and NTBFs in particular (Cooper and Bruno 1977). In knowledge-intensive sectors, opportunity identification and its eventual exploitation by entrepreneurs is influenced by their human capital and is more related to sectorial-specific competencies possessed by entrepreneurs (Shane 2000).

The great uncertainty that typically surrounds high-tech sectors, as well as the nontransactional and idiosyncratic nature of entrepreneurial judgement (Schumpeter 1911), makes it difficult for individuals to pursue business opportunities without creating a brand

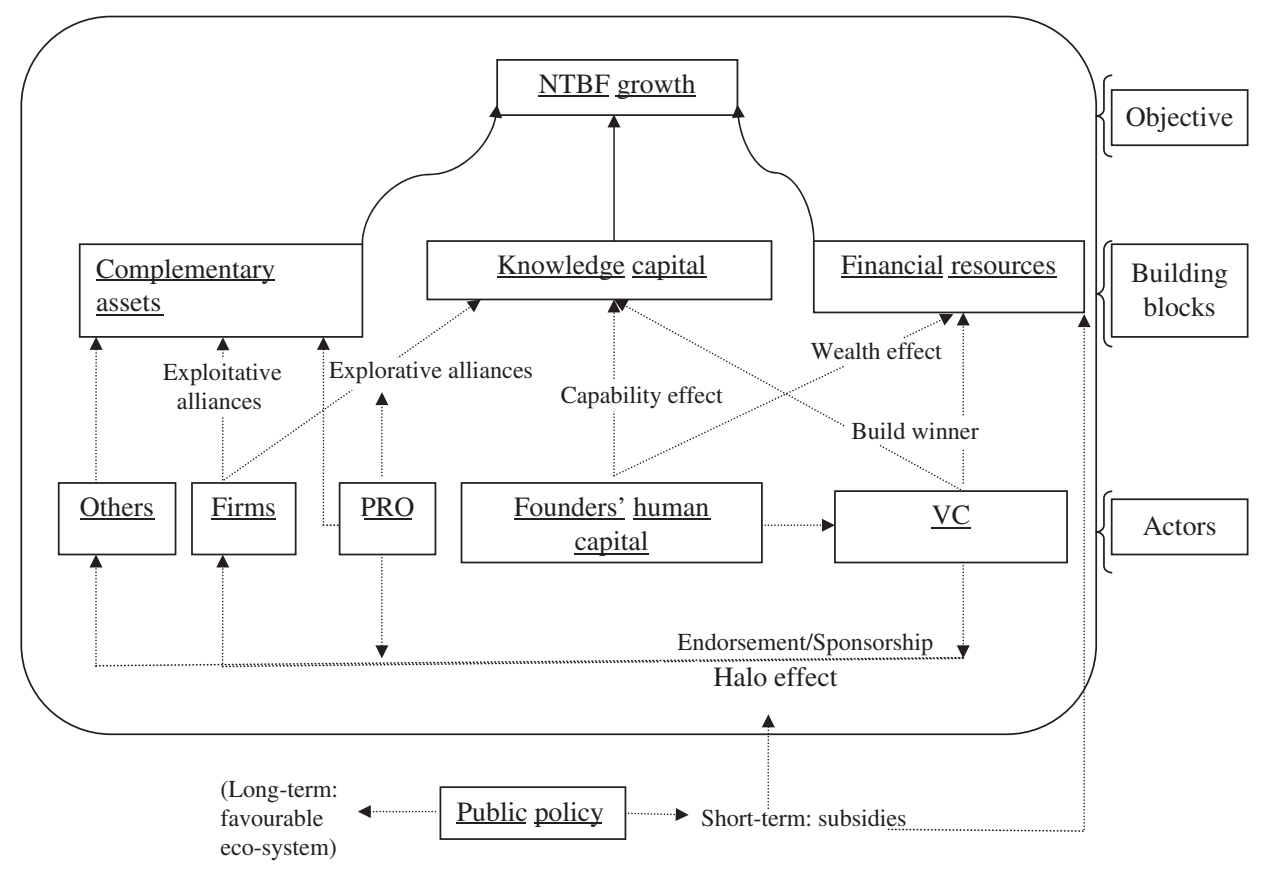

Figure 1. The heuristic firm growth model for European NTBFs 
new firm (e.g. the so-called "cephalisation" process first hypothesised by Knight in 1921). That business ideas are not tested also makes it difficult for would-be high-tech entrepreneurs to attract (particularly at the firm's inception) high-skilled workers, with the consequence that an NTBF's competences are very likely to largely coincide with those of their founders. In fact, the positive impact of founders' human capital on the growth performance of NTBFs is well documented not only in the USA (Eisenhardt and Schoonhoven 1990) but also in the European context by several studies (Almus and Nerlinger 1999 for Germany; Colombo and Grilli 2005, 2010 for Italy; Ganotakis 2012 for the UK). Overall, by highlighting this basic result, the empirical literature in this field also stresses other important related findings. First, the positive impact of founders' human capital may be not only a result of a "wealth effect" (i.e. that on average, high levels of human capital correspond to wealthier individuals and thus a greater level of personal financial resource investment in the start-up) but also prompted by a "capability effect" (i.e. the skills and competencies of the founding team; see, e.g. Colombo and Grilli 2005). In this respect, the jack of all trades-master of none's stylisation of the entrepreneur (Lazear 2005) appears not to be entirely profitable in high-tech sectors. More precisely, what appears to actually matter in fostering growth performance for high-tech start-ups is the specific rather than the generic (or "general") component of human capital (see Becker 1975 for the seminal distinction; Colombo and Grilli 2005, 2010 and Ganotakis 2012 for European evidence). The "specific" attribute includes all those technical and commercial competencies that founders can immediately apply to the new business and that have been obtained through professional experience in the markets in which the NTBF operates. "Generic" (or "general") human capital usually refers to all the knowledge that does not have a direct application into the business (e.g. primary education). The former component appears to be a sine qua non condition for ensuring success in high-tech industries. NTBFs whose founders are characterised by a strong technological core appear to be more likely to grow rapidly, particularly when these specific technical skills are combined with professional experience in commercialising products/services/technologies into markets.

A second important contributor to the knowledge capital necessary for the NTBF to remain competitive in markets and prosper is the support of venture capitalists (VCs). Particularly in Europe, this type of investors is found not only to play an important role as financier of new high-tech entrepreneurial ventures but also to provide guidance, monitoring and coaching functions to investee companies. Despite the "thinness" and embryonic stage of development of the VC industry in most EU Member States (Gregoriou, Kooli and KraussI 2006), VCs appear to exert a relevant "build winner" function (the definition is taken from Baum and Silverman 2004) in the European context. In this respect, the European VC market does not appear to be characterised by the strong sorting mechanisms between investors and investees indicated by Sørensen (2007) to exist in the US market, where VCs appear to be particularly able to "pick winners" rather than build them. Extant work on VC investments in Europe generally does not detect relevant "selection" effects (Engel 2002; Bottazzi, Da Rin, and Hellmann 2008; Colombo and Grilli 2010, 622-623). In other words, European VC investors do not always appear to invest in firms with (ex ante) superior growth prospects. Conversely, although the literature on the European context is still limited (most likely mirroring the smallness of the continental VC market), a relevant "build winner" function and a genuine adding-value function performed by VC is less controversial and it is put in evidence by Colombo and Grilli (2010) and Bertoni, Colombo and Grilli (2011) for the 
Italian case, by Engel and Keilbach (2007) for Germany, and by Peneder (2010) for Austria. This "build winner" or "coaching" function (Sapienza, Manigart and Vermeir 1996) is found to include a series of activities ranging from strategic consultancy activities (see Bertoni, Colombo and Grilli 2011 for Italy), to financial management (see Peneder 2010 for Austria), to labour market recruitment (see Bottazzi, Da Rin, and Hellmann 2008 for evidence on a pan-European sample). Networking is another fundamental "value-added" function exerted by VCs (Hsu 2006): in fact, VC-backed firms may benefit from the business contact network of VC investors, the network of other firms invested in by the same VC operators, or in the case of corporate venture capital, simply the industrial company's assets behind the financial branch. In all cases, NTBFs may gain access to resources that would most likely remain out of reach for a non-VC-backed venture (for European evidence on the networking function of VCs, see e.g., Sapienza, Manigart and Vermeir 1996 for France, the Netherlands and the UK; Bertoni, Colombo and Grilli 2011 for Italy). ${ }^{2}$

Finally, the building block represented by knowledge capital is completed by the intermediate link existing between founders and VC investors. Founders' human capital is in fact an important criterion for driving VC selection. In this manner, founder human capital other than a direct capability effect may also exert an indirect positive impact on NTBF growth by attracting VC investment. Audretsch and Lehmann (2004) found evidence of this indirect role regarding the educational achievements of the top management team members for a sample of German firms listed in the Neuer Markt. Lahr and Mina (2012) reported similar findings for the UK. Colombo and Grilli (2010) highlighted this indirect role as being particularly strong with regard to founders' economic education and managerial experience, testifying that beside its technological core, the NTBF requires economic and managerial competencies to interact with stakeholders, adopt an economically suitable strategic vision and, possibly, close eventual cognitive gaps with important potential investors.

\subsection{Financial Resources}

In their 1998 article in Research Policy, in discussing different policy schemes available in Europe for NTBFs, Storey and Tether acknowledge "the near universal recognition of the presence of market failure in the provision of finance for new technology-based firms" (1998, 1049). Accordingly, the presence of important financing constraints that hinder the development of European NTBFs has been documented by a great number of empirical studies (Revest and Sapio 2012 provide a review of this literature).

Simply, banks and other traditional lenders are reputed to be unsuitable to provide adequate financing resources for NTBFs due to the presence of high information asymmetries (Carpenter and Petersen 2002). The consequence is that, particularly at the beginning of operations, the firm strongly relies on the financial resources provided by its founders, familiar members and friends. Clearly, because high levels of human capital are more often associated with higher levels of income and wealth, the previously mentioned "wealth effect" of human capital is another channel through which entrepreneurs' human

\footnotetext{
${ }^{2}$ Bertoni, Colombo and Grilli $(2011,1039)$ report the following statement made by an entrepreneur: "The key advantage of being VC-backed resides in the ability of the VC investor to open doors that we could not open on our own".
} 
capital impacts NTBF growth. Accordingly, the initial size of new firm operations is found to be strongly determined by the level of founder human capital in a number of studies (e.g. Mata 1996 for Portugal), and the relationship is also found to hold for NTBFs (e.g. Colombo, Delmastro and Grilli 2004 for Italy). The capacity to fuel NTBF growth with internal resources appears to be also important in subsequent stages of the life cycle (see Westhead and Storey 1997 for UK; Bertoni, Colombo and Croce 2010 for Italy).

The problems associated with bank-lending conversely render VC financing particularly suitable for NTBFs. For European high-tech entrepreneurship, the problem is that the VC industry is still very underdeveloped in continental Europe (detailed figures are provided in Gregoriou, Kooli and Kraussl 2006 and European Parliament 2012). Historically, the overall value of VC investments in the USA exceeds by far the European one, but the wedge between the EU and USA in VC does not only appear remarkable in terms of quantity. According to an official report prepared for the European Parliament (2012), EU VCs' experience appears significantly lower than that of US VCs. Table 1 shows a comparison between EU and USA in terms of the number of funds managed by venture capital firms (a widely accepted proxy for VC's team experience). As to 2011, the number of VC teams that have raised two or more funds is 4.6 times greater in the USA than in Europe; and more interestingly, this ratio increases to 16.3 once one considers VC teams managing six or more funds.

Despite these gaps, VC investments are found to exert a positive impact on European NTBFs growth in the majority of studies. Positive (and economically significant) influence is found by Alemany and Marti (2005) in Spain, by Manigart and Van Hyfte (1999) in Belgium, by Bertoni, Colombo and Grilli (2011) in Italy, by Audretsch and Lehmann (2004) and Engel and Keilbach (2007) in Germany (for a "European exception", see Bottazzi and Da Rin 2002; see Bertoni, Colombo and Grilli 2011 for possible data issues explaining this discrepancy). The analysis of this literature leads us to identify two important facts.

First, beneath the average positive impact of VC in Europe, there seems to be significant variations within the macro "VC category" (Engel 2004). One of the most investigated sources of heterogeneity is represented by the institutional affiliation of VC investors (e.g. financial, corporate, bank-based, governmental). The available empirical evidence strongly suggests that this heterogeneity well translates into different investors' capabilities to foster European NTBFs growth (Lehmann 2006; Bertoni, Colombo and Grilli 2013; Devigne et al. 2013). Whatever the specific reasons individuated to explain such

Table 1. VC team's experience in EU versus USA in terms of number of funds raised (2011)

\begin{tabular}{lccc}
\hline No. of funds raised in the past & Europe & USA & Ratio USA/Europe \\
\hline Two or more & 73 & 334 & 4.6 \\
Three or more & 58 & 202 & 3.5 \\
Four or more & 28 & 132 & 4.7 \\
Five or more & 8 & 94 & 11.8 \\
Six or more & 4 & 65 & 16.3 \\
\hline
\end{tabular}

Source: European Parliament (2012). 
discrepancies at institutional level, all these contributions deliver the core message that not all VC investors are equally capable to enhance the performances of investee NTBFs.

The second important structural trait of the European VC market is its localness and, in this respect, it strongly conforms to more developed VC markets, in primis the US (Gompers and Lerner 2001; Lerner 2009). According to the recently developed VICO data-set that includes data on a large sample of high-tech entrepreneurial firms operating in seven European countries (Belgium, Finland, France, Germany, Italy, Spain and the UK), ${ }^{3}$ the internationalisation rate of EU VC investments is rather modest (only 16 per cent of the $1,903 \mathrm{VC}$ investments surveyed were cross-border). Importantly, these data also indicate a dramatically high geographical proximity between the location of the VC investor and that of investee NTBFs: for approximately 30 per cent of the VC investments, air distance between locations is less than $10 \mathrm{~km}$, and the percentage increases to approximately 50 per cent for an air distance of $50 \mathrm{~km}$. Recent econometric analyses confirm the relevance of spatial proximity in the VC decision process in very infrastructurally dense areas as well (see Lutz et al. 2013 and their analysis based on Germany). This "local" vocational characteristic, which appears to hold irrespective of the geographical context (i.e. it applies to Israel as well as to the USA and Europe), is an essential element to be considered by policy-makers who aim to sustain the creation and development of a flourishing VC market in the European context.

\subsection{Complementary Assets}

NTBFs are unlikely to possess all of the tangible and intangible assets necessary to sell their products/services/technologies in the corresponding markets. Simply, they must interface and establish links with other organisations and thus gain access to the assets of these organisations to sell the knowledge embodied in products/services/technologies (Teece 1986; Gans and Stern 2003). One fundamental type of such organisations includes universities and other-related public research institutions, henceforth PROs. In principle, informal links and formal explorative alliances established with PROs, which may also contemplate NTBFs' use of university facilities such as space and machinery in technology incubators or science parks, provide NTBFs with the physical and knowledge assets necessary for innovation and growth. The importance of these (formal and informal) "knowledge inputs" provided by PROs for NTBFs is well documented in the US context (Zucker and Darby 1996) and has also been validated in the European context with reference to NTBF growth performance, with the firm's absorptive capacity representing an important moderating factor (Audretsch and Lehmann 2005). In this respect and consistent with the literature on localised knowledge spillovers (Jaffe, Trajtenberg and Henderson 1993), geographical proximity to universities and location in technology incubators and science parks are found to facilitate European NTBFs' establishment of valuable links (Lindelöf and Löfsten 2004 for Sweden; Patton and Marlow 2011 for UK) even if overall, the role played by such structures in the European landscape in terms of spurring growth and

\footnotetext{
${ }^{3}$ The VICO data-set is the result of a research project that involved nine academic institutions funded by the 7th Framework Programme of the European Commission. See VICO (2011) for further details.
} 
innovation for incubated start-ups remains much more controversial (see, e.g., Schwartz 2011 on the German experience).

Other crucial providers of complementary assets to NTBFs are plausibly represented by (large) firms, and this essentially holds whether the NTBF decides to act in the market for technology/ideas or sell in the product market. In the former case, the NTBF's technology or services are simply sold or licensed to other firms and, thus, NTBF commercialisation relies completely on the acquirer firm(s). In the latter case, to access product markets, NTBFs must gain access to commercial assets (e.g. brand and distribution channels), which would be too costly or inefficient to replicate and they are thus often in need of stipulating commercial exploitative alliances with (large) incumbents. In this respect, European start-ups are found to face greater difficulties than their US counterparts in establishing commercial exploitative alliances with large firms (Colombo, Grilli and Piva 2006) or accessing markets for technology/ideas (Arora and Gambardella 2010). The results of an Organisation for Economic Co-operation and Development (OECD) survey in 2004 conducted on a sample of 773 companies and reported in Gambardella (2005) document that on average US firms spend 5.6 per cent of their R\&D budget on licensing fees while European firms spends only 0.8 per cent. The percentage of licensing revenues to R\&D budget was found on average of 6.0 per cent for US firms and again only of 3.1 per cent for European companies.

Note however that (large) firms do not represent a vital partner only for an NTBF's commercialisation strategy. As with PROs, they can be source of the development of new knowledge useful to NTBFs (explorative technological alliances) or be complementary in the combination of knowledge for exploitative purposes (e.g. exploitative technological alliances; see Mowery, Oxley and Silverman 1996). Allegedly, NTBFs are called to operate amidst continuous tension between exploitation activities that require the use of their knowledge and the exploration and acquisition of new knowledge and resources. The capacity to efficiently manage this trade-off, that is develop ambidexterity capabilities (Lavie, Kang and Rosenkopf 2011), is an important trait of successful NTBFs. Although (explorative or exploitative) technological alliances might entail important (opportunity) costs (Kelley and Nakosteen 2005), participation and inclusion in alliance technological networks is found to benefit NTBF growth performance on average (see Fontes and Coombs 1997; Colombo et al. 2009 and Parida, Westerberg and Frishammar 2012 for evidence on Europe), although the literature highlights important moderating factors at work. Focusing on the European-based evidence on NTBFs (and related), among these moderating factors, the absorptive capacity of members (de Jong and Freel 2010), network stability (Hurmelinna-Laukkanen et al. 2012), the location and heterogeneity of members (Colombo et al. 2009), as well as (of course) the innovativeness and prominence of members, appear to be important discriminating factors of network success.

Here, we focused on the two main actors providing complementary assets (PROs and large firms) necessary for NTBF growth, but of course, many other important stakeholders (ranging from non-research institutions to employees or end-users) can provide valuable resources for the development of the NTBF. What is arduous to controvert is the necessity for an NTBF to access resources provided by other actors of the economic system and the need to find suitable business partners. In this respect, NTBFs may encounter greater difficulties because their lack of a track record translates into deficiency in terms of reputation and, consequently, great uncertainty regarding their true value. In other words, 
those information asymmetries that may make it difficult for an NTBF to access traditional external financing resources may also make it difficult to access other equally needed complementary assets. Interestingly, the empirical literature on NTBF alliances emphasises that PROs and VCs may have an important sponsorship or endorsement function with respect to European NTBFs. VCs' brokerage and endorsement function may increase an NTBF's capacity to stipulate exploitative commercial alliances with other (large) firms (Colombo, Grilli and Piva 2006; Luukkonen, Deschryvere and Bertoni 2013), and formal or informal relationships with PROs may facilitate NTBF's access to alliance research networks (Colombo, Grilli and Piva 2006).

\subsection{Short-Term Role of Public Policy with Regard to High-Tech Entrepreneurship}

In the long-term, public policy is crucial in creating an institutional background encouraging the entrepreneurial spirit and innovative activities (Baumol 1990; Lundvall 2007 on National Innovation Systems). But the literature on high-tech entrepreneurship has singled two main motives that render a pervasive public intervention in the field compelling even in the shortterm (Peneder 2008). First, the presence of R\&D spillovers may induce high-tech entrepreneurial ventures to invest less than the social optimum (Griliches 1992). Second, as emphasised in the incipit of Section 2.2, a large body of empirical literature on entrepreneurship has indicated that (European) NTBFs contend with significant financial constraints.

The typical policy instrument aiming to solve these market failures is the provision of direct subsidies for NTBFs. The empirical literature on the effects of public subsidies on NTBFs is limited, with much of the attention being concentrated primarily on the related, albeit slightly different, question of whether R\&D subsidies provided to firms (not necessarily young and small ones operating in high-tech sectors) complement or replace private R\&D financing (see, e.g., Zuniga-Vicente et al. 2014 for a recent survey). Although on average, such studies highlight the positive effects of policy measures and do not support the full R\&D crowding-out hypothesis, the few contributions available with a more strict focus on European NTBFs (or related firms) cast more than one doubt on the effectiveness of this direct approach. Schneider and Veugelers (2010) fail to detect a significant positive effect exerted by subsidies on the performance of a sample of German young innovative companies (which include NTBFs). Similar findings also apply to the Italian context, in which, nonetheless, the impact of subsidies is found to be contingent on the "type" of granted support (Colombo, Giannangeli and Grilli 2013): in particular, if "automatic" subsidies (e.g. fiscal incentives) appear not to have an effect, "selective" ones (e.g. grants) have a greater and significant impact on the growth of NTBFs, particularly when the firm is very young and lacks a track record. These results suggest that the indirect and intangible "certification and halo" effect (Lerner 1999) of policy intervention may be more important for NTBFs than a direct (often small) financial contribution, exerting the same beneficial impact as that highlighted earlier and arising from the endorsement and sponsorship of other reputable organisations.

\section{Three “(Un-)easy Pieces” for European High-Tech Entrepreneurship Policy}

Building on the heuristic firm growth model for European NTBFs developed in the previous section (see, again, Figure 1), it is possible to detect three specific areas of intervention for 
European high-tech entrepreneurship policy-making. The policy mind map shown in Figure 2 , starting from the key actors and functions previously identified, illustrates these areas and the nexus between them and the NTBF growth drivers.

\subsection{Policy Focus on Firm Exit Rather than Entry}

In a famous article, Arthur (1996) proclaimed that high-tech entrepreneurship is not for everyone. The first building block of the heuristic model corroborates this statement: potentially successful NTBFs are risky business projects with highly intrinsic failure rates pursued by entrepreneurs endowed with great levels of specific human capital. From a welfare perspective, to have a consistent number of successful NTBFs, it would be important not only to just encourage more people to become entrepreneurs but rather to push those with the best chances to succeed to create their own high-tech businesses, that is those characterised by a high level of specific human capital. As a matter of fact, the opportunity cost for such individuals to invest their human capital in high-tech entrepreneurship instead of pursuing alternative options (e.g. being employed) is comparatively high in the European context. In other words, business failure is the norm rather than the exception in high-tech entrepreneurship, and both the administrative and cultural burdens associated with failure appear relevant in Europe. ${ }^{4}$

In this respect, at the European level, policy interventions are needed both at the regulatory and at cultural levels to lessen these burdens. As to the former, few European

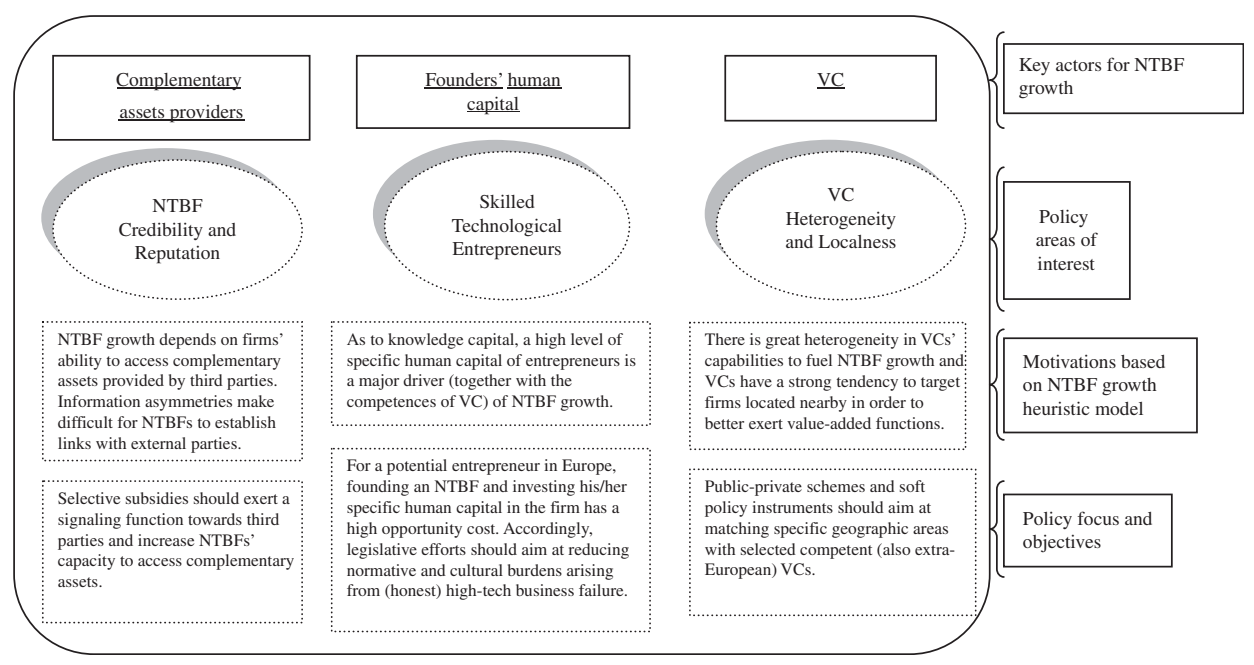

Figure 2. A policy mind map for the growth of European NTBFs

\footnotetext{
${ }^{4}$ In the USA, the maximum typical time from the end of the liquidation process until the bankruptcy is freed from debts rarely exceeds one year, in Germany it may take up to 6 years, in France up to 9 years (The Economist 2012).
} 
countries have in the recent past adopted new law reforms with regard to bankruptcy (e.g. Italy in 2007 and 2012, France 2006), but the focus remains primarily on increasing the options for rescuing financially distressed companies rather than enabling a rapid second beginning for an (honest) entrepreneur experiencing a business failure. ${ }^{5}$ In this respect, Armour and Cumming (2006) neatly describe how a regulatory switch to a "fresh and rapid start" may heavily affect (high-tech) entrepreneurship dynamics: for example, their estimates indicate that "the changes in the bankruptcy legislation in Germany (occurring during the late 1990s) increased the size of the German venture capital market by 6.4\%" (620). However, much still remains to be done. ${ }^{6}$ Overall, during 2000-2011, the European Union of 27 State Members produced only 28 reform measures enabling a rapid second start for failed entrepreneurs but generated 88 policy interventions reducing administrative burdens on the creation of start-ups (source: MICREF database, June 2014). However, if there is room to intervene on a regulatory and legislative basis, it is no less important from a public policy point of view to facilitate the reduction of those burdens associated with business failure that arise from a cultural sphere. The European "stigma" of business failure has deep historical roots (see, e.g. Thomas Mann 1901 in his masterpiece "Buddenbrooks") and it appears not to be marginal still nowadays (The Economist 2010). ${ }^{7}$

It is essential for Europe to develop the mentality that failure does not equate a "death sentence". Clearly, there may be multiple initiatives in the field, and all provide necessary returns from a long-term perspective: positive examples can be drawn from international experience, such as Singapore's award for the "best failed business" (its role in creating a fertile and risk-loving attitude in that specific context is analysed by Lerner 2009). In this respect, it is worth emphasising that the legislative and the cultural layers of policy intervention are mutually interdependent. However, a systematic approach at the European level that embraces both layers is still lacking in EU policy-making. The costs of this inactivity in terms of immaterialised business opportunities may be extremely high. Skype, the voice-over-IP service company, represents an example of a high-tech entrepreneurial venture that suffered a serious risk of not materialising (at least in the European context). Indeed, the earlier unsuccessful entrepreneurial experiences of its founders with Kazaa, a peer-to-peer file sharing application, did not help. As reported by one of the co-founders, Niklas Zennstrom (Dublin Web Summit October 2010), Kazaa was a financial failure but at the same time "probably the best experience in terms of learning". Certainly, this learning payoff was not

\footnotetext{
${ }^{5} \mathrm{An}$ interesting point of view, based on personal experience as a (high-tech) entrepreneur maturated both in the USA and Europe, on the differences in the applications of the "limited liability" norm between the two geographical contexts is offered by Gary Stewart in an article on Forbes.com from 19 November 2010 with the self-explanatory title "How Europe destroys entrepreneurship".

${ }^{6}$ Interestingly, this view is shared by the European Commission (2009, 74): "While most Member States have introduced or are introducing changes to their bankruptcy regulations on a step-by-step basis, the true importance of bankruptcy regulation for high-growth entrepreneurship is still to be fully recognised in most Member States".

${ }^{7}$ In the famous German masterpiece, one of the main characters of the novel defines failure as (p. 216): "more dreadful than death, that was catastrophe, ruin, shame, disgrace, misery, despair." More recently, The Economist (2010) states: "In America a failed start-up tends to be a badge of honour; in Europe, it often spells professional death." Recent systematic evidence highlights the presence of still important gaps in people's attitude towards business failure between the USA and EU (Gallup, 2010) and also show how these differences may have a significant impact on entrepreneurial dynamics (Simmons, Wiklund and Levie 2014). However, note that also dissonant views exist in the literature (e.g. Axelson and Martinovic, 2013).
} 
promptly recognised in Europe. As a matter of fact, the Skype founding team received over 20 rejections from European VCs asked to match seed funding provided by a US investor. At the end, Skype got external financing, was created in 2003, and it was a great success. It was sold to eBay in 2005 for 2.1 billion euros, later bought back and then re-sold to Microsoft for 6 billion euros. The possibility that a certain number of other Skype-like companies simply do not come to light because of the legislative and cultural burdens originating from previous entrepreneurial failings is worth of reflection by European policy-makers.

\subsection{Policy Recognition of the "Local" and Heterogeneous Nature of the Venture Capital Industry}

As illustrated in the heuristic model, venture capital often represents a sine qua non condition for the enablement of NTBF growth. At the same time, two important stylised facts emerge. First, venture capital is a broad and undifferentiated category that hides a great degree of heterogeneity, especially in the European context. These differences among investors range from their institutional nature to their managing experience. Quite naturally, these differences are also likely to translate into different capabilities of fostering the growth of the firms they invest. Second, regardless of the market's stage of development, that is, USA or EU, VCs very much appear to be "local" investors: they locate nearby investee firms so that they can better exert a monitoring function and provide value-added services. The combination of the two stylised facts-(a) not all VC investors are the same in their capabilities to build successful NTBFs, and (b) VCs are local investors; together with the observation that the European VC industry is still thin and relatively inexperienced-lead us to assert that an effective policy intervention in this area has to be able to match the right VCs to the right places, that is to attract (extra-European) specific VC operators towards specific areas of interest. In this domain, the implementation of public-private co-financing schemes, which also aim at attracting international investors, seem particularly appropriate (international examples are the Yozma program in Israel and the New Zealand Venture Investment Fund. See Lerner 2010 for a description and discussion). Equally important, such a policy would require prior effort in terms of the identification and eventual matching of both geographical eco-systems (jointly created by local facilities, universities, and entrepreneurial and innovativeness culture) and selected credible (foreign) investors for those specific areas. Then, publicly sponsored territorial marketing activities directed towards these (international) investors (such as meetings, events, planned visits, road shows, and regulatory advisory and consultancy services) are likely to be more effective than other general measures that are merely monetary or fiscal (for the importance of these "soft" public services at the local level, see also Hospers, Desrochers and Sautet 2009 and Nishimura and Okamuro 2011).

In this respect, if the importance of a flourishing venture capital industry is well understood at the EU policy level, the implemented and envisaged measures appear to have not yet acknowledged the local nature of the business and the typically high degree of heterogeneity among its actors. In particular, beginning with the first programmatic documents (e.g. "Risk capital: a key to job creation in the European Union", Commission of the European Communities 1998) much of the focus has remained anchored to a "national" playing field, and most of the efforts have been devoted to removing tax obstacles and avoiding double-taxation regimes across national systems to favour cross-border investments (see, e.g. the European Commission 2011 "Single Market Act l", April, p. 6). 
Without neglecting the importance of these macro policy interventions, nascent venture capital markets would certainly benefit from the parallel local micro-approach depicted earlier.

\subsection{Policy "Certification" Effect}

As highlighted in the heuristic model, the NTBF growth also depends on a firm's capability to access complementary assets and establish formal and informal links with third parties. In this respect, third parties may find difficult to evaluate the quality of NTBFs, since they are young and operate in highly uncertain and turbulent business environments. If from one side, VC investors and PROs may endorse an NTBF; on the other side, we have seen that public subsidies may also exert a "certification and halo" effect.

The recent economic and financial crisis is constraining budgets for the direct sustainment of (high-tech) entrepreneurship. However, NTBFs may still benefit from a direct policy-making intervention that, without providing large financial support, is nevertheless able to exert its "stamp of approval" on selected business projects and facilitate endorsed NTBF's relationships with third parties. As previously suggested (see Section 2.4), such intervention requires the implementation of policy measures explicitly and strictly targeted to high-tech entrepreneurial ventures, or in other words, a policy shift from horizontal "automatic" measures to vertical "selective" schemes. Apart from granting financial resources, these schemes must be able to trigger and magnify the certification effect of the policy measure. Allegedly, it is of paramount relevance that they be administered by appointed committees composed of competent professionals and experts. The better the selectors' reputations, the greater the certification effect stemming from their decision will be. Then, it is equally important that application procedures do not entail substantial participation costs. This element is important first because in this manner, it is possible to avoid any adverse self-selection mechanisms, which are extremely likely in this context because time's opportunity cost is an increasing function of competence and skills and the absence of founders' slack may cause valuable business projects to remain out of competition. Second, certification is powerful only to the extent that it has been gained at the expense of many contestants, so triggering strong competition among applicants is a necessary condition for activating the certification effect.

The US Small Business Innovation Research (SBIR) program represents the oftencited example of an effective selective policy scheme aimed towards the creation and growth of viable NTBFs. Established in 1982, this scheme led to the development of very well-known high-tech "gazelles" (e.g. Intel, Compaq, Symantec), and its validity has been recognised and acknowledged in a vast spectrum of scientific and non-scientific contributions (see Lerner 2009 for an updated review; Wallsten 2000 for a partial exception). Many scholars and observers note that one of the principal benefits for SBIR-supported firms was due to the certification effect this subsidy exerted toward third parties (see Lerner 1999 and more recent evaluation exercises like Wessner 2008).

Accordingly, the recent proposal by the EU Commission in Europe 2020 agenda to create a European-based program ("SME Instrument" in Horizon 2020) inspired by the American SBIR scheme should be welcomed. However, from a policy perspective, it must be stressed that this proposal may represent only a single step in the right direction. The implementation of SBIR-like schemes in geographical contexts other than the US has sometimes been far from producing the expected outcomes (see OECD 2010 for a complete review). The main challenge that policy-makers must face appears to be the avoidance of a merely superficial 
and formal re-proposition of the SBIR program without consideration that in this context, the "devil is in the details" (Connell 2009). In this respect, questions such as the following are not of secondary importance: (a) will the (relatively more) bottom-up approach followed by the EU Commission be equally effective as the top-down system pursued by (some) US Federal Agencies in the administration of funds? and (b) will EU Member States continue to accept the absence of any system of quotas in the allocation rules? To the extent that these critical issues will be solved to ensure the highest possible degree of competition among the largest number of applicants, the consequent "halo and certification" effect triggered by the policy measure is likely to be extremely beneficial from a social welfare point of view.

\section{Concluding Remarks}

The absence of rapid-growth NTBFs in the European context is deemed by European policy-makers to be one of the most worrisome structural weaknesses in Europe and a primary obstacle to meeting the goal of becoming the most dynamic and competitive knowledge-based economy in the world. European policy-makers recognise that without a more vibrant and vital high-tech entrepreneurship sector, the European objective of "smart" growth will simply remain out of reach. This paper departs from this starting point and, based on the extant conceptual and empirical literature on the determinants of high-tech entrepreneurial venture growth in Europe, develops a heuristic firm growth model for European NTBFs. This way, we synthesise the scientific evidence on the topic to provide a simplified and solid interpretative framework for the phenomenon.

By individuating the main critical drivers of European NTBF growth, the heuristic model also delineate three specific areas of intervention for policy-making aiming to sustain the growth of NTBFs: (1) reducing the social and regulatory cost of (honest) failure to increase the quality rather than the quantity of high-tech entrepreneurs, (2) acknowledging the local nature of the venture capital industry and promoting territorial marketing initiatives to attract (international) capable VC players; and (3) in the face of national hard budget constraints and scarce financial resources, leveraging the "halo and certification" effect of direct public intervention in the high-tech entrepreneurship segment to ease NTBFs' access to private external financing sources and complementary assets provided by key stakeholders.

Both the heuristic firm growth model and its policy prescriptions have wider applicability than mere Europe and refer to more general points. For example, some of the lines of reasoning here developed acknowledge the importance of the local dimension but, at the same time, challenge the policy ambition of re-creating ex novo elsewhere some clones of the Silicon Valley model (for an analysis on the uniqueness of its history see Kenney 2000), without considering the specificities of the NTBF growth process in different eco-systems. By the same token, our contribution similarly to other recent ones (see, e.g. Vivarelli 2013 as regards entrepreneurship in developing economies) enriches our insights on the "varieties of capitalism" approach (Hall and Soskice 2001), by enquiring what the entrepreneurial dynamics here analysed have in common and what not with those of other different institutional contexts.

Without neglecting this broader perspective, our European focus enables us to deliver a more incisive message to European policy-makers. In this regard, if recent initiatives have steered EU policy in the right direction (e.g. the recent "SME Instrument"), in the author's view, in most Member States there is large room to intervene in these three areas to induce the abrupt and radical change of course in the investigated dynamics that is needed to meet 
the ambitious objectives of the Europe 2020 agenda. Quite obviously, we are conscious that any policy intervention implemented for NTBF growth must be realised using a more general and macroeconomic policy approach to be truly effective. In this respect, the heuristic firm growth model for NTBF here presented is only a stylised representation of the process of development of NTBFs, and future empirical research needs to complement this picture with new elements. Nevertheless, by documenting on scientific grounds the importance of these three specific "pieces" for policy-making in high-tech entrepreneurship, our contribution is aimed towards increasing awareness and sensibility at the policy level with regard to these themes. Allegedly, it invokes a higher degree of factual effort than that produced up to this point by European policy-makers and legislators to render "easy" these only seemingly "uneasy" areas of policy intervention.

\section{Acknowledgements}

This paper stems from the keynote speech held at the 32nd Japanese Annual Small Business Society (JASBS) National Annual Conference, 22 September 2012, Kaetsu University, Tokyo, Japan. The author is grateful to participants of this event for their encouraging remarks. He is also indebted for constructive comments and suggestions provided by: Editor Mark Lorenzen, two anonymous reviewers, Sergio Mariotti, Mariana Mazzucato, Hiroyuki Okamuro, Michael Peneder, Josh Siepel, David Storey, Marco Vivarelli, Lorenzo Zirulia, participants to the 35th DRUID Celebration Conference, Barcelona, Spain, 17-19 June 2013 and to seminars held at the Università Cattolica del Sacro Cuore in Piacenza on 17 April 2013 and at the Social Policy Research Unit (SPRU) of the University of Sussex on 13 June 2014. In the last stage, the paper greatly benefited from my Visiting Professorship at SPRU at the University of Sussex during May and June 2014. The views expressed in this paper and eventual errors are only my responsibility.

\section{References}

Alemany, L., and J. Martì. 2005. "Unbiased Estimation of Economic Impact of Venture Capital Backed Firms.” EFA 2005 Moscow Meetings Paper.

Almus, M., and E. A. Nerlinger. 1999. "Growth of New Technology-based Firms: Which Factors Matter?" Small Business Economics 13: $141-154$.

Armour, J., and D. Cumming. 2006. "The Legislative Road to Silicon Valley.” Oxford Economic Papers 58: $596-635$.

Arora, A., and A. Gambardella. 2010. "Ideas for Rent: An Overview of Markets for Technology." Industrial and Corporate Change 19: $775-803$.

Arthur, W. B. 1996. "Increasing Returns and the New World of Business." Harvard Business Review 74: 100-109.

Audretsch, D., and E. Lehmann. 2004. "Financing High-Tech Growth: The Role of Banks and Venture Capitalists." Schmalenbach Business Review 56: 340-357.

Audretsch, D., and E. Lehmann. 2005. "Does the Knowledge Spillover Theory of Entrepreneurship Hold for Regions." Research Policy 34 : 1191-1202.

Axelson, U., and M. Martinovic. 2013. European Venture Capital: Myths and Facts. British Private Equity \& Venture Capital Association. Baum, J., and B. Silverman. 2004. "Picking Winners or Building Them? Alliance, Intellectual, and Human Capital as Selection Criteria in Venture Financing and Performance of Biotechnology Startups." Journal of Business Venturing 19: 411-436.

Baumol, W. T. 1990. "Entrepreneurship: Productive, Unproductive and Destructive." Journal of Political Economy 98: 893-921.

Becker, G. S. 1975. Human Capital. New York: National Bureau of Economic Research.

Bertoni, F., M. G. Colombo, and A. Croce. 2010. "The Effect of Venture Capital Financing on the Sensitivity to Cash Flow of Firm's Investment." European Financial Management 16: 528-551. 
Bertoni, F., M. G. Colombo, and L. Grilli. 2011. "Venture Capital Financing and the Growth of High-tech Start-Ups: Disentangling Treatment from Selection Effects." Research Policy 40: 1028-1043.

Bertoni, F., M. G. Colombo, and L. Grilli. 2013. "Venture Capital Investor Type and the Growth Mode of New Technology-based Firms." Small Business Economics 40: 527-552.

Bottazzi, L., and M. Da Rin. 2002. "Venture Capital in Europe and the Financing of Innovative Companies." Economic Policy 17: $229-269$.

Bottazzi, L., M. Da Rin, and T. Hellmann. 2008. "Who are the Active Investors? Evidence from Venture Capital." Journal of Financial Economics 89: 488-512.

Carpenter, R. E., and B. C. Petersen. 2002. "Capital Market Imperfections, High-tech Investment, and New Equity Financing." Economic Journal 112: F54-F72.

Chandler, G., and S. Hanks. 1994. "Founder Competence, the Environment and Venture Performance." Entrepreneurship Theory and Practice 18: 77-89.

Colombo, M. G., M. Delmastro, and L. Grilli. 2004. "Entrepreneurs' Human Capital and the Start-up Size of New Technology-based Firms." International Journal of Industrial Organization 22: 1183-1211.

Colombo, M. G., S. Giannangeli, and L. Grilli. 2013. "Public Subsidies and the Employment Growth of High-tech Start-ups: Assessing the Impact of Selective and Automatic Support Schemes." Industrial and Corporate Change 22: 1273-1314.

Colombo, M. G., and L. Grilli. 2005. "Founders' Human Capital and the Growth of New Technology-based Firms: A Competence Based View." Research Policy 34: 795-816.

Colombo, M. G., and L. Grilli. 2010. "On Growth Drivers of High-tech Start-ups: Exploring the Role of Founders' Human Capital and Venture Capital." Journal of Business Venturing 25: 610-626.

Colombo, M. G., L. Grilli, S. Murtinu, L. Piscitello, and E. Piva. 2009. "Effects of International R\&D Alliances on Performance of High-tech Start-ups: A Longitudinal Analysis." Strategic Entrepreneurship Journal 3: 346-368.

Colombo, M. G., L. Grilli, and E. Piva. 2006. "In Search for Complementary Assets: Alliance Strategies of New Technology-based Firms." Research Policy 35: 1166-1199.

Commission of the European Communities. 1998. Risk Capital: A Key to Job Creation in the European Union. Luxembourg: Office for Official Publications of the European Communities. ISBN 92-828-3707-6.

Connell, D. 2009. "Creating an EU SBIR Programme: Lessons from the UK and Proposals for EC Action." Workshop on "Public Procurement of Innovation - Feasibility of an EU Scheme", October 20-21.

Cooper, A. C., and A. V. Bruno. 1977. "Success Among High-technology Firms." Business Horizons 20: 16-22.

Czarnitzki, D., and J. Delanote. 2013. "R\&D Subsidies to Small Young Companies: Should the Independent and High-tech Ones be Favoured?" $35^{\circ}$ DRUID Conference Proceedings, Barcelona, Spain.

Devigne, D., T. Vanacker, S. Manigart, and I. Paeleman. 2013. "The Role of Domestic and Cross-Border Venture Capital Investors in the Growth of Portfolio Companies." Small Business Economics 40: 553-573.

de Jong, J. P. J., and M. Freel. 2010. "Absorptive Capacity and the Reach of Collaboration in High Technology Small Firms." Research Policy 39: 47-54.

Eisenhardt, K. M., and C. B. Schoonhoven. 1990. "Organizational Growth: Linking Founding Team, Strategy, Environment and Growth Among U.S. Semiconductor Ventures, 1978-1988." Administrative Science Quarterly 35: 504-529.

Engel, D. 2002. "The Impact of Venture Capital on Firm Growth: An Empirical Investigation." Discussion Paper No. 02-02. Mannheim: Centre for European Economic Research (ZEW)

Engel, D. 2004. "The Performance of Venture-backed Firms: The Effect of Venture Capital Company Characteristics." Industry and Innovation 11: 249-263.

Engel, D., and M. Keilbach. 2007. "Firm Level Implication of Early Stage Venture Capital Investment: An Empirical Investigation.” Journal of Empirical Finance 14: 150-167.

European Commission. 2000. Funding of New Technology-based Firms by Commercial Banks in Europe. Brussels, ISBN 92-828-9731-1.

European Commission. 2009. European Competitiveness Report 2008. http://ec.europa.eu/enterprise/newsroom/cf/_getdocument.cfm? doc_id $=4058$

European Commission. 2010. Europe 2020: A Strategy for Smart, Sustainable and Inclusive Growth. http://ec.europa.eu/eu2020/

European Commission. 2011. Single Market Act. Twelve Levers to Boost Growth and Strengthen Confidence. http://eur-lex.europa.eu/ LexUriServ/LexUriServ.do?uri=COM:2011:0206:FIN:EN:PDF 
European Parliament. 2012. Potential of Venture Capital in the European Union. Directorate General for Internal Policies. Policy Department A: Economic and Scientific Policy Industry, Research and Energy. http://www.europarl.europa.eu/committees/en/ studiesdownload.html?languageDocument=EN\&file $=66851$

Eurostat. 2013. Gross Domestic Expenditure on R\&D (GERD) \% of GDP. http://epp.eurostat.ec.europa.eu/tgm/table.do?tab=table\&init= 1 \&plugin $=1$ \&language $=$ en\&pcode $=\mathrm{t} 2020 \_20$

Fontes, M., and R. Coombs. 1997. "The Coincidence of Technology and Market Objectives in the Internationalisation of New Technologybased Firms." International Small Business Journal 15: 14-35.

Gallup. 2010. Entrepreneurship in the EU and Beyond: A survey in the EU, EFTA Countries, Croatia, Turkey, the US, Japan, South Korea and China. Flash Eurobarometer No. 298, May. Brussels: European Commission.

Gambardella, A. 2005. "Assessing the Market for Technology in Europe." Presentation at EPO-OECD BMWA International Conference on Intellectual Property as an Economic Asset: Key Issues in Valuation and Exploitation, June 30-July 12005, Berlin. www.oecd.org/sti/ipr Ganotakis, P. 2012. "Founders' Human Capital and the Performance of UK New Technology Based Firms." Small Business Economics 39: 495-515

Gans, J. S., and S. Stern. 2003. "The Product Market and the Market for 'Ideas': Commercialization Strategies for Technology Entrepreneurs." Research Policy 32: 333-350.

Gompers, P., and J. Lerner. 2001. "The Venture Capital Revolution.” Journal of Economic Perspectives 15: 145-168. Gregoriou, G. N., M. Kooli, and M. Kraussl. 2006. Venture Capital: A European Perspective. Amsterdam: Elsevier.

Griliches, Z. 1992. "The Search for R\&D Spillovers." Scandinavian Journal of Economics 94: S29-S47.

Hall, P. A., and D. Soskice. 2001. Varieties of Capitalism: The Institutional Foundations of Comparative Advantage. Oxford: Oxford University Press.

Hospers, G.-J., P. Desrochers, and F. Sautet. 2009. "The Next Silicon Valley? On the Relationship Between Geographical Clustering and Public Policy." International Entrepreneurship and Management Journal 5: 285-299.

Hsu, D. H. 2006. "Venture Capitalists and Cooperative Start-up Commercialization Strategy." Management Science 52: $204-219$.

Hurmelinna-Laukkanen, P., H. Olander, K. Blomqvist, and V. Panfilii. 2012. "Orchestrating R\&D Networks; Absorptive Capacity, Network Stability, and Innovation Appropriability." European Management Journal 30: 552-563.

Jaffe, A. B., M. Trajtenberg, and R. Henderson. 1993. "Geographic Localization of Knowledge Spillovers as Evidenced by Patent Citations." Quarterly Journal of Economics 63: 577-598.

Kelley, D. J., and R. A. Nakosteen. 2005. "Technology Resources, Alliances and Sustained Growth in New, Technology-Based Firms." IEEE Transactions on Engineering Management 52: 292-300.

Kenney, M. 2000. Understanding Silicon Valley: The Anatomy of an Entrepreneurial Region. Stanford, CA: Stanford University Press. Knight, F. 1921. Risk, Uncertainty, and Profit. Boston, MA: Houghton Mifflin.

Lahr, H., and A. Mina. 2012. "Coaching or Selection? Venture Capital and Firms' Patenting Performance." FINNOV Series Publication No. 3.9 .

Lavie, D., J. Kang, and L. Rosenkopf. 2011. "Balance within and across Domains: The Performance Implications of Exploration and Exploitation in Alliances." Organization Science 22: 1517-1538.

Lazear, E. P. 2005. "Entrepreneurship.” Journal of Labor Economics 23: 649-680.

Lehmann, E. 2006. "Does Venture Capital Syndication Spur Employment Growth and Shareholder Value? Evidence from German IPO Data." Small Business Economics 26: 455-464.

Lerner, J. 1999. "The Government as Venture Capitalist: the Long-Run Impact of the SBIR Program.” Journal of Business 72: $285-318$. Lerner, J. 2009. Boulevard of Broken Dreams: Why Public Efforts to Boost Entrepreneurship and Venture Capital Have Failed-And What to Do About It. Princeton, NJ: Princeton University Press.

Lerner, J. 2010. "The Future of Public Efforts to Boost Entrepreneurship and Venture Capital." Small Business Economics 35: 255-264. Lindelöf, P., and H. Löfsten. 2004. "Proximity as a Resource Base for Competitive Advantage: University-Industry Links for Technology Transfer." Journal of Technology Transfer 29: 311-326.

Little, A. D. 1977. New Technology-based Firms in the United Kingdom and the Federal Republic of Germany. London: Wilton House. Lundvall, B.-A․ 2007. "National Innovation Systems-Analytical Concept and Development Tool." Industry and Innovation 14: 95-119. Lutz, E., M. Bender, A.-K. Achleitner, and C. Kaserer. 2013. "Importance of Spatial Proximity Between Venture Capital Investors and Investees in Germany." Journal of Business Research 66: 2346-2354.

Luukkonen, T., M. Deschryvere, and F. Bertoni. 2013. "The Value Added by Government Venture Capital Funds Compared with Independent Venture Capital Funds." Technovation 33: 154-162. 
Manigart, S., and M. Van Hyfte. 1999. "Post-Investment Evolution of Venture Backed Companies." In Frontiers of Entrepreneurship Research, edited by P. Reynolds, W. Bygrave, S. Manigart, C. Mason, G. Meyer, H. J. Sapienza, and K. Shaver. Wellesley, MA: Babson College.

Mann, T. 1901. Buddenbrooks. English Edition: 1924. London: Martin Secker \& Warburg.

Mata, J. 1996. "Market, Entrepreneurs and the Size of New Firms." Economics Letters 52: 89-94.

Mowery, D. C., J. E. Oxley, and B. S. Silverman. 1996. "Strategic Alliances and Interfirm Knowledge Transfer." Strategic Management Journal 17: 77-91.

Nishimura, J., and H. Okamuro. 2011. "Subsidy and Networking: The Effects of Direct and Indirect Support programs of the Cluster Policy." Research Policy 40: 714-727.

OECD. 2010. Public Procurement Programmes for Small Firms: SBIR-Type Programmes. Innovation Policy Platform Document no. 48136807 .

Parida, V., M. Westerberg, and J. Frishammar. 2012. "Inbound Open Innovation Activities in High-Tech SMEs: The Impact on Innovation Performance.” Journal of Small Business Management 50: 283-309.

Patton, D., and S. Marlow. 2011. "University Technology Business Incubators: Helping New Entrepreneurial Firms to Learn to Grow." Environment and Planning C: Government and Policy 29: 911-926.

Peneder, M. 2008. "The Problem of Private Under-Investment in Innovation: A Policy Mind Map." Technovation 28: 518-530.

Peneder, M. 2010. "The Impact of Venture Capital on Innovation Behaviour and Firm Growth.” Venture Capital 12: 83-107.

Penrose, E. 1959. The Theory of the Growth of the Firm. Oxford: Oxford University Press.

Revest, V., and A. Sapio. 2012. "Financing Technology-based Small Firms in Europe: What do we know?" Small Business Economics 39: 179-205.

Sapienza, H. J., S. Manigart, and W. Vermeir. 1996. "Venture Capital Governance and Value Added in Four Countries." Journal of Business Venturing 11: 439-469.

Schneider, C., and R. Veugelers. 2010. "On Young Highly Innovative Companies: Why they Matter and How (not) to Policy Support them." Industrial and Corporate Change 19: 969-1007.

Schumpeter, J. A. 1911. The Theory of Economic Development. Cambridge, MA: Harvard University Press Originally printed in 1934.

Schwartz, M. 2011. "Incubating an Illusion? Long-term Incubator Firm Performance after Graduation." Growth and Change 42: $491-516$. Shane, S. 2000. "Prior Knowledge and the Discovery of Business Opportunities." Organization Science 11: 448-469.

Simmons, S. A., J. Wiklund, and J. Levie. 2014. "Stigma and Business Failure: Implications for Entrepreneurs' Career Choices." Small Business Economics 42: 485-505.

Sørensen, M. 2007. "How Smart is Smart Money? A Two-Sided Matching Model of Venture Capital." Journal of Finance 62: $2725-2762$. Storey, D. J., and B. S. Tether. 1998. "Public Policy Measures to Support New Technology-based Firms in the European Union." Research Policy 26: 1037-1057.

Teece, D. J. 1986. "Profiting from Technological Innovation: Implications for Integration, Collaboration, Licensing, and Public Policy." Research Policy 15: 285-305.

The Economist. 2010, June 10. Europe's Tech-entrepreneurs: Blooming. http://www.economist.com/node/16317551

The Economist. 2012, July 28. Les Misérables. http://www.economist.com/node/21559618

VICO. 2011. Policy Lessons from the VICO Project. Final EU project report (theme SSH-2007-1.2.3 - Grant Agreement 217485). http:// www.vicoproject.org/doc/policy/VICO_FinalPolicyBrief.pdf

Vivarelli, M. 2013. "Is Entrepreneurship Necessarily Good? Microeconomic Evidence from Developed and Developing Countries." Industrial and Corporate Change 22: 1453-1495.

Zucker, L. G., and M. R. Darby. 1996. "Star Scientists and Institutional Transformation: Patterns of Invention and Innovation in the Formation of the Biotechnology Industry." Proceedings of the National Academy of Sciences 93: 12709-12716.

Zuniga-Vicente, A. J., C. Alonso-Borrego, F. J. Forcadell, and J. I. Galàn. 2014. "Assessing the Effect of Public Subsidies on Firm R\&D Investment: A Survey." Journal of Economic Surveys 28: 36-67.

Wallsten, S. J. 2000. "The Effects of Government-Industry R\&D Programs on Private R\&D: The Case of the Small Business Innovation Research Program." RAND Journal of Economics 31: 82-100.

Westhead, P., and D. J. Storey. 1997. "Financial Constraints on the Growth of High Technology Small Firms in the United Kingdom." Applied Financial Economics 7: 197-201.

Wessner, C. W. 2008. An Assessment of the SBIR Program 2008. Washington, DC: National Research Council (US) Committee, National Academies Press. 